\title{
Evaluation of the Antioxidant Activities of Organic Extracts from Ammodaucus leucotrichus Coss \& Dur Fruit Part Harvested from the Algerian Sahara
}

\author{
${ }^{1}$ Department of Biology, Abou Bekr Belkaid Tlemcen University, Algeria \\ ${ }^{2}$ Research Center on Physical and Chemical Analysis (CRAPC) Tipaza, Algeria \\ ${ }^{3}$ Department of Biology, Abou Bekr Belkaid Tlemcen University, Algeria \\ ${ }^{4}$ Department of Nature and Life Science, Salhi Ahmed University Center Naama, Algeria
}

Imad Abdelhamid El Haci' ${ }^{1,2 *}$, Wissame Mazari ${ }^{3}$, Mohamed Gherib ${ }^{4}$ and Fawzia Atik Bekkara ${ }^{1}$

*Corresponding author: Imad Abdelhamid El Haci, PhD, Scientific and Technical Research Center for Physical Chemical Analysis (CRAPC), BP 384, Zone Industrielle Bou-Ismail RP 42004, Algeria

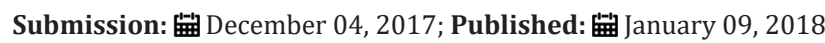

\begin{abstract}
Aromatic and medicinal plants are a good source of natural preparations containing effective bioactive compounds which can be used for different applications. This work aims to evaluate the antioxidant activity of some organic extracts of Ammodaucus leucotrichus Coss \& Dur fruit part. The whole plant was collected from the region of Beni Abbas (Bechar-Algeria). Five organic extracts were obtained and the evaluation of the antioxidant activity was performed by six conventional methods. Polar organic extracts exhibited more antioxidant power then non polar extracts. The level of phenolic compounds was moderate in all extracts. The investigation of the antioxidant activity of organic extracts from fruit part of Ammodaucus leucotrichus revealed a moderate activity tested by six conventional methods.
\end{abstract}

Keywords: Ammodaucus leucotrichus; Medicinal plant; Antioxidant activity; Organic extracts; Phenolic compounds

\section{Introduction}

Ammodaucus leucotrichus Coss \& Dur is a medicinal plant used in folk medicine in Algeria. Ammodaucus leucotrichus is a small annual plant, $10-12 \mathrm{~cm}$ high, glabrous with erect, finely striated stems. The leaves are finely dissected and slightly fleshy. The flowers are small, with 5 free petals. The fruit is a diachene, $6-10 \mathrm{~mm}$, long and is covered with dense silky white hairs. It usually flowers in early spring (February to April). The plant is common in the Algerian

Table 1: Different uses of Ammodaucus leucotrichus (Coss \& Dur) in traditional folk medicine in Algeria.

\begin{tabular}{|c|c|c|}
\hline \multicolumn{2}{|c|}{ Arabic Denomination } & Traditional Uses \\
\hline $\begin{array}{c}\text { Ammodaucus leucotrichus Coss \& Dur } \\
\text { (Apiaceae) }\end{array}$ & $\begin{array}{c}\text { Leaves are used for chest complaints. In the Tassili (South of Algeria), leaves are used } \\
\text { to aromatise tea, and its powder is a much appreciated spice for food } \\
\text { Arabic: kammûn es- } \\
\text { sofi, el massoufa } \\
\text { are used either as a powder or in a decoction to treat gastric-intestinal pain and } \\
\text { indigestion. It is also frequently used, as an infusion, for diverse infantile diseases of } \\
\text { the digestive apparatus: dysentery, nausea, regurgitation, vomiting. It is used also to } \\
\text { treat patients suffered with high blood pressure }\end{array}$ \\
\hline
\end{tabular}

\section{Material and methods}

\section{Plant materials}

The whole plant was collected from the province of BeniAbes (west-southern of Algeria-region of Bechar). The fruits of Ammodaucus leucotrichus were dried away from direct sunlight. Dried plant material was then crushed into a mortar and stored at very low temperature until further use [5].
Sahara (Bechar, Djanet, and El Golea), its presence is also observed in the Canary Islands [1-3]. Ammodaucus leucotrichus is used for the treatment of many diseases (Table 1). In the continuity of our works on this species, the present study reports the determination of the phenolic and flavonoid contents and, also, the assessment of the antioxidant activity of different organic extracts of the fruit part of this plant [4]. 


\section{Total phenolic contents}

Total phenolic was estimated by the Folin-Ciocalteu method [6]. $0.1 \mathrm{~mL}$ of each sample was mixed with $2 \mathrm{~mL}$ of sodium carbonate $(2 \%)$ freshly prepared, the whole was mixed. After $5 \mathrm{~min}, 100 \mu \mathrm{L}$ of Folin-Ciocalteu reagent $(1 \mathrm{~N})$ were added to the mixture and left for $30 \mathrm{~min}$. The values of absorbance were recovered at $750 \mathrm{~nm}$ against a blank. A calibration curve was performed under the same operating conditions using gallic acid. The results were expressed as mg gallic acid equivalent per gram of dry extract (mg GAE/g).

\section{Total flavonoid contents}

The total flavonoid content was determined by the method described by Ardestani \& Yazdanparast [7]. Each sample $(500 \mu \mathrm{L})$ was mixed with $2 \mathrm{~mL}$ of distilled water and subsequently with $150 \mu \mathrm{L}$ of a $\mathrm{NaNO}_{2}$ solution $(15 \%) .150 \mu \mathrm{L}$ of aluminum chloride $\left(\mathrm{AlCl}_{3}\right)$ solution $(10 \%)$ was added and allowed to stand for $6 \mathrm{~min}$. Then, $2 \mathrm{~mL}$ of $\mathrm{NaOH}$ solution (4\%) was added to the mixture. Immediately, distilled water was added to bring the final volume to $5 \mathrm{~mL}$ and the mixture was thoroughly mixed and allowed to stand for $15 \mathrm{~min}$. Absorbance of the mixture was determined at $510 \mathrm{~nm}$. Results were expressed as catech in equivalent per gram of dry extract (mg CEQ/g).

\section{Study of the Antioxidant Activity}

\section{Evaluation of the total antioxidant capacity (TAC)}

An aliquot of $0.1 \mathrm{~mL}$ of sample solution was combined with $1 \mathrm{ml}$ of reagent solution $(0.6 \mathrm{M}$ sulfuric acid, $28 \mathrm{mM}$ sodium phosphate, and $4 \mathrm{mM}$ ammonium molybdate). The tubes were capped and incubated at $95{ }^{\circ} \mathrm{C}$ for $90 \mathrm{~min}$. After the samples had cooled to room temperature, the absorbance was measured at $695 \mathrm{~nm}$. A typical blank solution contained $1 \mathrm{~mL}$ of reagent solution and the appropriate volume of the same solvent used for the sample and it was incubated under the same conditions as the rest of the samples. For positive control, acid ascorbic was used at the same conditions [8].

\section{Ferric reducing antioxidant power (FRAP)}

Samples and ascorbic acid were used at different concentrations. $1 \mathrm{~mL}$ of each sample was mixed with phosphate buffer $(2.5 \mathrm{~mL}$, $\left.0.2 \mathrm{~mol} \mathrm{~L}^{-1}, \mathrm{pH} 6.6\right)$ and potassium ferricyanide $\left[\mathrm{K}_{3} \mathrm{Fe}(\mathrm{CN})_{6}\right](2.5 \mathrm{~mL}$, $30 \mathrm{mmol} \mathrm{L}^{-1}$ ). The mixture was incubated at $50{ }^{\circ} \mathrm{C}$ for $20 \mathrm{~min}$. A $2.5 \mathrm{~mL}$ of TCA $\left(0.6 \mathrm{~mol} \mathrm{~L}^{-1}\right)$ was added to the mixture, which was then centrifuged for $10 \mathrm{~min}$ at $3000 \mathrm{~g}$. The supernatant $(2.5 \mathrm{~mL})$ was mixed with distilled water $(2.5 \mathrm{~mL})$ and $\mathrm{FeCl} 3\left(0.5 \mathrm{~mL}, 6 \mathrm{mmol} \mathrm{L}^{-1}\right)$, and the absorbance was measured at 700nm [9].

\section{DPPH- scavenging activity}

A methanolic solution $(50 \mu \mathrm{L})$ of each sample at different concentrations was added to $1.95 \mathrm{~mL}$ of DPPH- (2,2-Diphenyl1-Picrylhydrazyl) solution $\left(6 \times 10^{-5} \mathrm{M}\right.$ in methanol $)$. The studied compounds were tested with methanol as control, BHA (Beta Hydroxy Acid), ascorbic acid and quercetin as antioxidant references. The absorbance at $515 \mathrm{~nm}$ was determined after $30 \mathrm{~min}$.
The absorbance (A) of the control and samples was measured, and the DPPH- scavenging activity (SA), in percentage, was determined as follow:

$\mathrm{SA} \%=[($ Acontrol - Asample $) /$ Acontrol $] \times 100$

IC50 (inhibition concentration of 50\%) was obtained graphically from nonlinear regression analysis [10].

\section{$\mathrm{H}_{2} \mathrm{O}_{2}$ scavenging activity}

A solution of $\mathrm{H}_{2} \mathrm{O}_{2}(20 \mathrm{mM})$ was prepared in phosphate buffered saline (PBS, $0.1 \mathrm{M}, \mathrm{pH} 7.4$ ). $1 \mathrm{~mL}$ of sample or positive control (BHA and $\alpha$-tocopherol) in methanol was added to $2 \mathrm{~mL}$ of $\mathrm{H}_{2} \mathrm{O} 2$ solution in PBS. The absorbance was measured at $230 \mathrm{~nm}$, after $10 \mathrm{~min}$ [11]. The percentage of $\mathrm{H}_{2} \mathrm{O}_{2}$ scavenged was calculated:

$\%$ of scavenged $\mathrm{H}_{2} \mathrm{O}_{2}=[($ Acontrol-Asample $) /$ Acontrol $] \times 100$

\section{Hydroxyl scavenging assay}

$\mathrm{OH}$-radicals were generated from $\mathrm{FeSO}_{4}$ and $\mathrm{H}_{2} \mathrm{O}_{2}$, and detected by their ability to hydroxylate salicylate. The reaction mixture contained $1 \mathrm{~mL}$ of $\mathrm{FeSO}_{4}(1.5 \mathrm{mM}), 0.7 \mathrm{~mL}$ of $\mathrm{H}_{2} \mathrm{O}_{2}(6 \mathrm{mM}), 0.3 \mathrm{~mL}$ of sodium salicylate $(20 \mathrm{mM})$ and different concentrations of organic extracts tested. After incubation for $1 \mathrm{~h}$ at $37^{\circ} \mathrm{C}$, the absorbance was measured at $562 \mathrm{~nm}$. The percentage of scavenging effect was calculated as:

$\%$ of Scavenging $=\left[1-\left(A_{1}-A_{2}\right) / \times A_{0}\right] \times 100$

Where $A_{0}$ was the absorbance of the control (without extract) and $\mathrm{A} 1$ was the absorbance in the presence of the extract and $A_{2}$ was the absorbance without sodium salicylate. IC50 (inhibition concentration of $50 \%$ ) was obtained graphically from nonlinear regression analysis [12].

\section{$\beta$-Carotene bleaching method}

A stock solution of $\beta$-carotene was prepared with $0.5 \mathrm{mg}$ of $\beta$-carotene in $1 \mathrm{~mL}$ of chloroform, $25 \mu \mathrm{L}$ of linoleic acid and $200 \mathrm{mg}$ of Tween 40. The chloroform was evaporated and $100 \mathrm{~mL}$ of oxygenated distilled water were added to the residue. $350 \mu \mathrm{L}$ of each sample were added to $2.5 \mathrm{~mL}$ of the above mixture. The test tubes were incubated at $50{ }^{\circ} \mathrm{C}$ for $2 \mathrm{~h}$, together with two blanks, one contained BHA as a positive control and the other contained the same volume of methanol instead of the extracts. The absorbance was measured at $470 \mathrm{~nm}$. Antioxidant activities (inhibition percentages, $\mathrm{I} \%$ ) of the samples were calculated using the following equation:

\section{$\mathrm{I} \%=(\mathrm{A} \beta$-carotene after $2 \mathrm{~h}$ assay $/$ Ainitial $\beta$-carotene $) \times 100$}

where A $\beta$-carotene after $2 \mathrm{~h}$ assay is the absorbance of $\beta$-carotene after $2 \mathrm{~h}$ assay remaining in the samples and $A$ initial $\beta$-carotene is the absorbance of $\beta$-carotene at the beginning of the experiments. IC50 (inhibition concentration of 50\%) was obtained graphically from nonlinear regression analysis [13]. All tests were carried out in triplicate and results were reported as means \pm SD of triplicates. 


\section{Results and Discussion}

Table 2: Yield of extraction, phenolic contents and antioxidant activity (DPPH- scavenging, $\mathrm{OH}$ - scavenging and $\beta$-carotene bleaching methods) of the different organic extracts of fruit part of Ammodaucus leucotrichus.

\begin{tabular}{|c|c|c|c|c|c|c|}
\hline \multirow{2}{*}{$\begin{array}{l}\text { Organic Extracts } \\
\text { of Ammodaucus } \\
\text { leucotrichus }\end{array}$} & \multirow{2}{*}{$\begin{array}{c}\text { Yield of } \\
\text { Extraction (\%) }\end{array}$} & \multirow{2}{*}{$\begin{array}{l}\text { Phenolic Contents } \\
\text { (mg GAE/g) }\end{array}$} & \multirow{2}{*}{$\begin{array}{l}\text { Flavonoid } \\
\text { Contents (mg } \\
\text { CEQ/g) }\end{array}$} & $\mathrm{IC}_{50}(\mu \mathrm{g} / \mathrm{mL})$ & \multirow{2}{*}{$\begin{array}{c}\mathrm{IC}_{50}(\mu \mathrm{g} / \mathrm{mL}) \mathrm{OH} \bullet \\
\text { Scavenging }\end{array}$} & \multirow{2}{*}{$\begin{array}{c}\mathrm{IC}_{50}(\mu \mathrm{g} / \mathrm{mL}) \\
\begin{array}{c}\beta \text {-carotene } \\
\text { Bleaching }\end{array}\end{array}$} \\
\hline & & & & $\begin{array}{c}\text { DPPH• } \\
\text { Scavenging }\end{array}$ & & \\
\hline Methanol Extract & $10.02 \pm 0.49$ & $118.69 \pm 8.5$ & $66.65 \pm 0.37$ & $38.10 \pm 2.54$ & $43.33 \pm 1.32$ & $191.53 \pm 1.53$ \\
\hline Ethanol Extract & $9.92 \pm 0.28$ & $160.61 \pm 6.28$ & $87.79 \pm 0.51$ & $29.03 \pm 1.85$ & $89.67 \pm 3.33$ & nd \\
\hline Acetone Extract & $7.22 \pm 0.48$ & $152.26 \pm 4.44$ & $97.38 \pm 1.3$ & $41.31 \quad 0.56$ & $96.33 \pm 5.21$ & nd \\
\hline $\begin{array}{l}\text { Ethyl Acetate } \\
\text { Extract }\end{array}$ & $4.78 \pm 0.81$ & $20.9 \pm 3.12$ & $21.48 \pm 0.84$ & nd & nd & nd \\
\hline Chloroform Extract & $5.71 \pm 0.88$ & $12.49 \pm 1.17$ & $15.94 \pm 1.38$ & nd & nd & nd \\
\hline Ascorbic Acid & & & & $2.48 \pm 0.09$ & $61.83 \pm 1.98$ & nd \\
\hline BHA & & & & $2.61 \pm 0.13$ & nd & $4.26 \pm 0.98$ \\
\hline Quercetin & & & & $2.59 \pm 0.15$ & nd & nd \\
\hline
\end{tabular}

Methanol and ethanol extracts showed yields of the order of $10.02 \pm 0.49 \%$ and $9.92 \pm 0.28 \%$, respectively (Table 2). An extraction yield of methanol extract (maceration) of Ammodaucus leucotrichus fruit part of about $20.4 \%$ was reported by Sifi et al. [14]. The contents of this plant on phenolics and flavonoids in their different organic extracts were important in polar organic extracts. The most important phenolic contents were observed in ethanol extract (160.61 $\pm 6.28 \mathrm{mg} \mathrm{GAE} / \mathrm{g}$ ). While the most important flavonoid contents were recorded in acetone extract $(97.38 \pm 1.31 \mathrm{mg}$ CEQ/g). Chloroform extract contained the less important contents in those compounds (Table 2). Some species in Apiaceae family contain significant levels of phenolics and flavonoids. The study of Saeed et al. [15] on Torilis leptophylla methanolic extract reported high contents on those compounds $(121.9 \pm 3.1 \mathrm{mg}$ GAE/g and $60.9 \pm 2.2 \mathrm{mg} \mathrm{RTE} / \mathrm{g}$, respectively). Another study on three species of Apiaceae: Heracleum lasiopetalum Boiss, Kelussia odoratissima Mozaff and Echinophora platyloba DC, reported important levels of phenolics (from 74 to $120 \mathrm{mg}$ TAE/g), and flavonoids (from 7.63 to 14.52mg RE/g) [16].

The evaluation of antioxidant activity of the organic extracts was made by six conventional methods. The antioxidant activity of Apiaceae was investigated by several authors in the literature. Chandran et al. [17] investigated the antioxidant activity of aqueous and methanolic extracts of leaf part of Ardisia solanaceae Roxb. The methanolic extract of this plant revealed more antioxidant activity compared to the aqueous extract. Interesting antioxidant activity was reported by the authors of this publication [17]. Pirbalouti et al. [16] in their study on three species of Apiaceae family, endemic in Iran, reported an interesting antioxidant power of their methanol extracts tested by: the DPPH- test, reduction of iron and the ABTStest.

The antioxidant activity of organic extracts of the fruit part of Ammodaucus leucotrichus that we evaluated was moderate overall antioxidant tests used in our study (Figures 1-3). Extracts from polar solvents showed more antioxidant activity than those from non-polar one. In TAC test, we noticed that the methanol extract has shown the most important antioxidant activity compared to the other extracts organic, but lower than that of ascorbic acid. For DPPH- scavenging test, organic extracts: ethanol, methanol and acetone, had presented a moderate antioxidant activity with values of IC50 in the order of $29 \pm 1.85 \mu \mathrm{g} / \mathrm{mL}, 38.10 \pm 2.54 \mu \mathrm{g} / \mathrm{mL}$ and $41 \pm 0.56 \mu \mathrm{g} / \mathrm{mL}$, respectively. Nevertheless, these extracts remain less active compared to the used positive controls. In $\mathrm{H}_{2} \mathrm{O}_{2}$ scavenging test, methanolic and ethanolic extracts presented an important activity superior to that of the positive controls used (BHA and tocopherol). The other extracts were also active. The chemistry behind this test is based on a transfer of electrons and proton between the antioxidant and hydrogen peroxide by reducing it in a water molecule. Measurement in the UV band makes this test very sensitive and estimate with a critical eye [18].

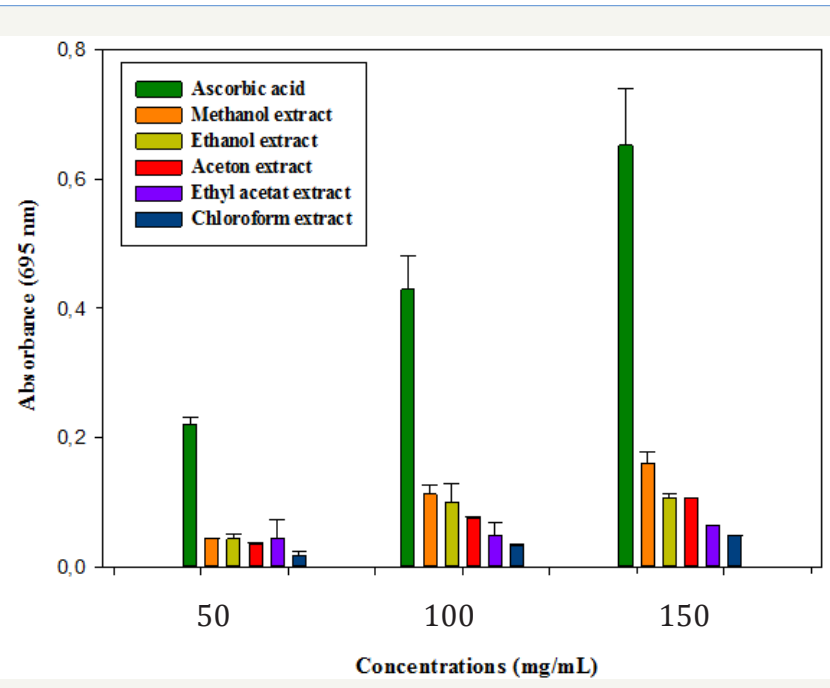

Figure 1: Total antioxidant activity of the different organic extracts of fruit part of Ammodaucus leucotrichus. 


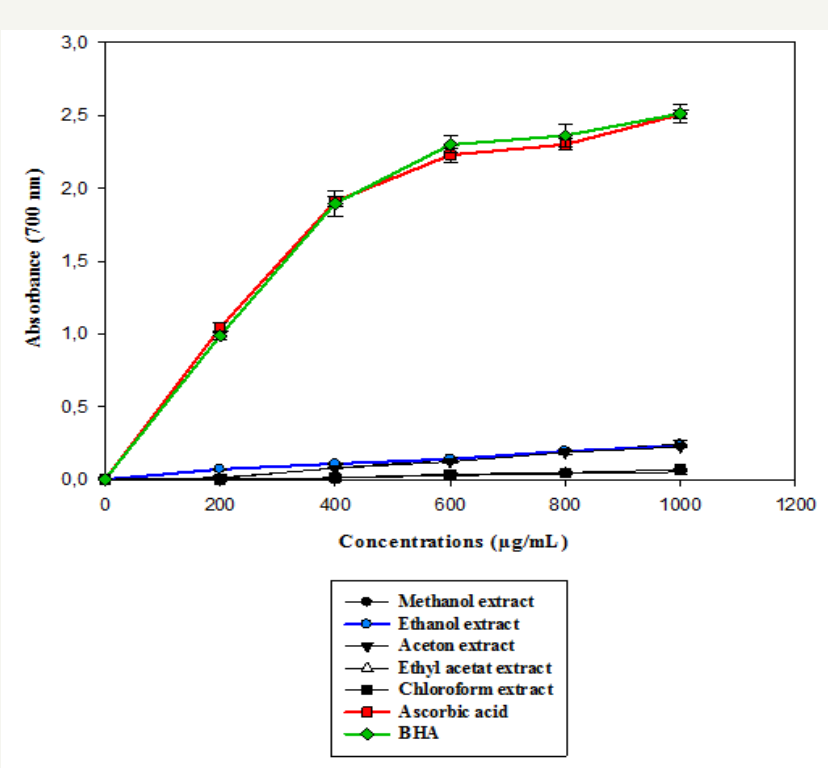

Figure 2: Reducing power activity (FRAP) of the different extract of fruit part of Ammodaucus leucotrichus.

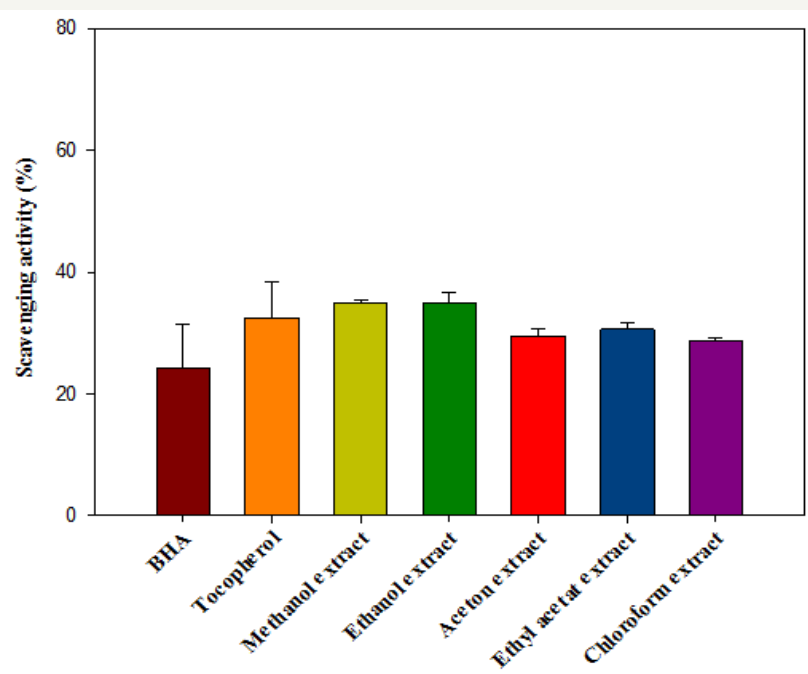

Figure 3: $\mathrm{H}_{2} \mathrm{O}_{2}$ scavenging activity of the different organic extracts of the fruit part of Ammodaucus leucotrichus.

Good antioxidant activity was recorded in $\mathrm{OH}$ - radicals scavenging test for methanolic extract, more interesting than the positive control (ascorbic acid). Assessment of the activity of an extract to scavenge the $\mathrm{OH}$ - radical is important, due to the high reactivity of this radical, which reacts with a wide range of molecules found in living cells (such as: sugars, lipids, proteins, nucleotides and so on). In the test of $\beta$-carotene bleaching, all organic extracts showed moderate activity and only the methanolic extract presented an IC50 $(191.53 \pm 1.53 \mu \mathrm{g} / \mathrm{mL})$ which is significantly lower than that of the BHA $(4.26 \pm 0.98 \mu \mathrm{g} / \mathrm{mL})$. In the FRAP test, all organic extracts showed very modest antioxidant activity.

\section{Conclusion}

Valorization of local flora is an important priority to find new interesting compounds that can be used in different fields. One of the endemic plants in Algeria, Ammodaucus leucotrichus was the subject of some scientific papers. In this study, we concluded that secondary metabolites from this plant exhibited a moderate antioxidant activity. These results help us to orientate our future studies in other directions of research.

\section{Acknowledgment}

The authors gratefully acknowledge Dr Hassani Fayçal (University of Tlemcen) for his help in the identification of the plant.

\section{Conflict of Interest Statement}

The authors declare that there is no conflict of interest.

\section{Financial Support}

This work was supported by the Laboratory of Research in Natural Products, Faculty SNVSTU, University of Tlemcen, Algeria.

\section{References}

1. Quezel P, Santa S (1963) New flora of Algeria and southern desert regions, CNRS, Paris, France.

2. Benhouhou S (2005) A Guide to Medicinal plants in North Africa: database on Medicinal plants, IUCN center for Mediterranean cooperation, Mâlaga, Spain.

3. Chehma A (2006) Catalog of spontaneous plants of the Algerian northern Sahara. Faculty of Sciences and Engineering Sciences, Protecting Ecosystems in Arid and Semi-Arid Zones Laboratory, University of Ouargla, Algeria.

4. ElHaci IA, Bekhechi C, Bekkara FA, Mazari W, Gherib M, et al. (2014) Antimicrobial activity of Ammodaucus leucotrichus fruit oil from Algerian Sahara. Nat Prod Commun 9(5): 711-712.

5. Hammiche V, Maiza K (2006) Traditional medicine in Central Sahara: Pharmacopoeia of Tassili N'ajjer. J Ethnopharmacol 105(3): 358-367.

6. Vermerris W, Nicholson R (2006) Isolation and identification of phenolic compounds, phenolic compound biochemistry. Springer, Dordrecht. pp.151-191.

7. Ardestani A, Yazdanparast R (2007) Inhibitory effects of ethyl acetate extract of Teucrium polium on in vitro protein glycoxidation. Food Chem Toxicol 45(12): 2402-2411.

8. Prieto P, Pineda M, Aguilar M (1999) Spectrophotometric quantitation of antioxidant capacity through the formation of a phosphomolybdenum complex: specific application to the determination of vitamin E. Anal Biochem 269(2): 337-341.

9. Yang J, Guo J, Yuan J (2008) In vitro antioxidant properties of rutin. Food Sci Technol 41: 1060-1066.

10. Benhammou N, Bekkara AF, Kadifkova Panovska T (2009) Antioxidant activity of methanolic extracts and some bioactive compounds of Atriplex halimus. Compte rendu chimie 12(12): 1259-1266.

11. Bhatia L, Bishonoi H, Chauhan P, Kinja K, Shailesh S (2011) In vitro comparative antioxidant activity of ethanolic extracts of Glycosmis pentaphylla and Bauhinia variegate. Recen Res Sci Technol 3(7): 1-3.

12. Wang H, Gao XD, Zhou GC, Cai L, Yao WB (2008) In vitro and in vivo antioxidant activity of aqueous extract from Choerospondias fruit. Food Chem 106(3): 888-895.

13. Ebrahimabadi AH, Bidgoli DZ, Mazoochi A, Kashi FJ, Batooli H (2010) Essential oil composition, antioxidant and antimicrobial activity of the leaves and flowers of Chaerophyllum macropodum Boiss. Food Control 21(8): 1173-1178. 
14. Sifi I, Benaddou FZ, Yousfi M (2015) Antioxidant and antimicrobial activities of phenolic extracts of endemic plants Marrubium deserti and Ammodaucus leucotrichus from Algeria, World Academy of Science, Engineering and Technology International Journal of Biotechnology and Bioengineering, Algeria 9(1).

15. Saeed N, Khan MR, Shabbir M (2012) Antioxidant activity, total phenolic and total flavonoid contents of whole plant extracts Torilis leptophylla $\mathrm{L}$. BMC Complem Altern Med 12: 221-233.

16. Pirbalouti AG, Setayesh M, Siahpoosh A, Mashayekhi H (2013) Antioxidant activity, total phenolic and flavonoids contents of three herbs used as condiments and additives in pickles products. Herba Polonica 59(3): 51-62.

17. Chandran PR, Manju S, Vysakhi MV, Shaji PK, Achuthan Nair G (2013) In vitro antioxidant potential of methanolic and aqueous extracts of Ardisia solanacea Roxb. leaf J Pharm Res 6(5): 555-558.

18. Ruch RJ, Cheng SJ, Klaunig JE (1989) Prevention of cytotoxicity and inhibition of intercellular communication by antioxidant catechins isolated from Chinese green tea. Carcinogenesis 10(6): 1003-1008. 